This report was prepared as an account of work sponsored by an agency of the United States Government. Neither the United States Government nor any agency thereof, nor any of their employees, makes any warranty, express or implied, or assumes any legal liability or responsibility for the accuracy, completeness, or usefulness of any information, apparatus, product, or process disclosed, or represents that its use would not infringe privately owned rights. Reference herein to any specific commercial product, process, or service by trade name, trademark, manufacturer, or otherwise does not necessarily constitute or imply its endorsement, recommendation, or favoring by the United States Government or any agency thereof. The views and opinions of authors expressed herein do not necessarily state or reflect those of the United States Government or any agency thereof.

\title{
National High-Level Waste Systems Analysis Plan
}

\author{
Keith Kristofferson \\ Thomas P. Oholleran \\ Robert H. Powell \\ Elizabeth. C. Thiel
}

Published May 1995

\section{Idaho National Engineering Laboratory Radioactive Waste Technical Support Program \\ Lockheed Idaho Technologies Company Idaho Falls, Idaho 83415}

\author{
Prepared for the \\ U.S. Department of Energy \\ Assistant Secretary for Environmental Management \\ Under DOE Idaho Operations Office \\ Contract DE-AC07-94ID13223
}




\section{DISCLAIMER}

Portions of this document may be illegible in electronic image products. Images are produced from the best available original document. 


\begin{abstract}
This document details the development of modeling capabilities that can provide a system-wide view of all U.S. Department of Energy (DOE) high-level waste (HLW) treatment and storage systems. This model can assess the impact of budget constraints on storage and treatment system schedules and throughput. These impacts can then be assessed against existing and pending milestones to determine the impact to the overall $\mathrm{HLW}$ system. A nation-wide view of waste treatment availability will help project the time required to prepare $\mathrm{HLW}$ for disposal. The impacts of the availability of various treatment systems and throughput can be compared to repository readiness to determine the prudent application of resources or the need to renegotiate milestones.
\end{abstract}





\section{EXECUTIVE SUMMARY}

This document details the development of modeling capabilities that can provide a systemwide view of all U.S. Department of Energy (DOE) high-level waste (HLW) treatment and storage systems. This model can assess the impact of budget constraints on storage and treatment system schedules and throughput. These impacts can then be assessed against existing and pending milestones to determine the impact to the overall HLW system. A nation-wide view of waste treatment availability will help project the time required to prepare $\mathrm{HLW}$ for disposal. The impacts of the availability of various treatment systems and throughput can be compared to repository readiness to determine the prudent application of resources or the need to renegotiate milestones.

A prototype of the system model has been constructed using available hard data pertaining to schedules, processing options, and throughput. The prototype model has been constructed in such a way as to allow expansion to incorporate other factors (programmatic, institutional, etc.) at a later date. The influence of soft data will be evaluated with the model by establishing discreet sets of input variables (scenarios) that reflect the consequences of soft variables (e.g., the effects of stakeholder involvement).

While the initial version of the model will not perform detailed cost estimation, throughput, which relates to facility size, can be used to compare facility costs on a relative basis. Either schedule or throughput can be selected as the independent variable. For example, schedule can be fixed in order to study the effects of legally binding agreements on facility size (throughput). Conversely, throughput can be fixed to examine the influence of budget constraints on the need to renegotiate existing agreements.

Five sets of independent variables that represent "scenarios" are developed. Once a scenario is completely defined, dependent variables are calculated to provide the output. The output includes event flags to indicate if pre-selected conditions or milestones are not satisfied when the scenario is run. An example would be if the repository opening is delayed, thereby requiring a larger amount of interim vitrified waste storage than originally planned for.

The following five scenarios will be examined with the initial model in order to efficiently develop the model and to demonstrate capabilities for further development:

\section{Baseline}

The base-case scenario will use a fixed schedule defined by existing court orders and agreements. A detailed waste treatment schedule will be developed from site operating plans and will include negotiated and envisioned milestones. Process throughput will be estimated, along with interim storage requirements. Repository receipts will be calculated using existing Office of Civilian Radioactive Waste Management (RW) and Environmental Management (EM) documents designating shipping rates for final disposal. In the event that data is nonexistent, assumptions will be made and documented in the model. 


\section{No Repository}

This scenario will also use a fixed schedule defined by existing court orders and negotiated agreements. A detailed waste treatment schedule is being developed, with process throughput and interim storage requirements being estimated from facility schedules and operating plans. However, in this case, the national repository is abandoned in lieu of monitored retrievable storage. DOE will then size, construct, and operate an adequate monitored retrievable interim storage facility to U.S. Nuclear Regulatory Commission requirements.

\section{Reduce Throughput}

This scenario will perturb the base-case scenario by reducing throughput between HLW storage and the treatment facility at all sites by $30 \%$ and calculating a new schedule. This scenario would simulate a reduction in funding (assuming that construction funds for the Savannah River Site and West Valley Demonstration Project are already committed) and would be used to illustrate the impact on existing agreements and court orders.

\section{Delay Repository 30 Years}

This scenario would recompute the base case, with the repository opening being delayed 30 years (to 2045). This scenario would illustrate the impact of a delay in repository operations on interim storage needs and would require additional construction. This case will assume that all current agreements and court orders are met other than those requiring deep geologic disposal. The increased life-cycle costs of this option will be determined by the system cost model. Minimization of interim storage would be accomplished by defining the throughput from treatment as being equivalent to the transportation throughput available to each site. The transportation throughput available to each site would be determined from the total transportation throughput available, based upon the total amount of waste currently in storage.

\section{Delay Repository 30 Years and Renegotiate Milestones}

This scenario would assume a 30-year delay in repository operations and calculate new schedules for Hanford and the Idaho National Engineering Laboratory (INEL), assuming minimal interim storage at those sites. Minimizing interim storage would be accomplished by defining the throughput from treatment as being equivalent to the transportation throughput available to each site. The transportation throughput available to each site would be determined from the total transportation throughput available divided proportional to the total amount of waste currently in storage. This scenario would illustrate the latitude for adjustment in DOE's HLW treatment schedule, while minimizing interim storage costs, and it would help define issues for renegotiating orders and agreements.

The transportation system and waste packaging operations at the repository will not be explicitly modeled, but their effects can be taken into account by varying the rate of HLW received at the repository. 
Experience gained during testing of the model will be used to expand and refine the data. Sensitivity analyses will demonstrate which variables have the most profound impacts on the output. The model will be exercised using "hard" variables (schedule, throughput and capacity) developed and incorporated from the site's existing operating plans. "Soft" variables (institutional, programmatic, regulatory, financial, and technical) will also affect the performance of all or parts of the national HLW management system. Scenarios will be created that incorporate soft variable perturbations to the base-case scenario or to the other scenarios to help assess the impact of these issues on facility schedules, capacity, or throughput and ultimately on the ability of sites to prepare HLW for shipment to the repository. The results of this exercise will be published in a later report. 



\section{CONTENTS}

ABSTRACT $\ldots \ldots \ldots \ldots \ldots \ldots \ldots \ldots \ldots \ldots \ldots \ldots \ldots \ldots \ldots \ldots \ldots \ldots \ldots \ldots \ldots \ldots$

EXECUTIVE SUMMARY $\ldots \ldots \ldots \ldots \ldots \ldots \ldots \ldots \ldots \ldots \ldots \ldots \ldots \ldots$

1. INTRODUCTION $\ldots \ldots \ldots \ldots \ldots \ldots \ldots \ldots \ldots \ldots \ldots \ldots \ldots \ldots \ldots \ldots$

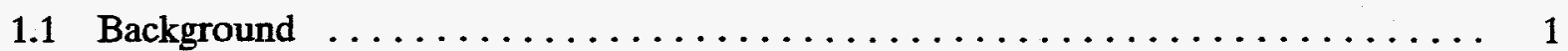

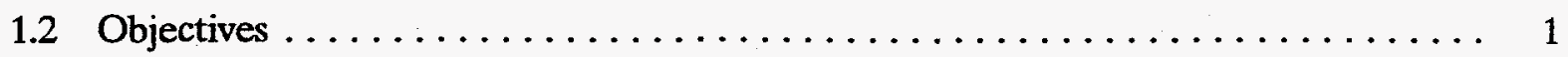

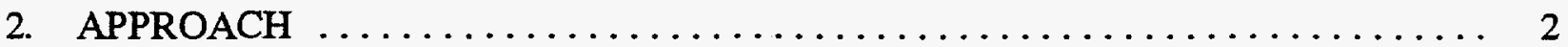

3. DESCRIPTION OF THE MODEL $\ldots \ldots \ldots \ldots \ldots \ldots \ldots \ldots \ldots \ldots \ldots \ldots$

3.1 Model Capabilities $\ldots \ldots \ldots \ldots \ldots \ldots \ldots \ldots \ldots \ldots \ldots \ldots \ldots \ldots \ldots$

3.2 Vensim Specific Output $\ldots \ldots \ldots \ldots \ldots \ldots \ldots \ldots \ldots \ldots \ldots \ldots \ldots \ldots$

3.3 General Assumptions and Constraints $\ldots \ldots \ldots \ldots \ldots \ldots \ldots \ldots \ldots \ldots$

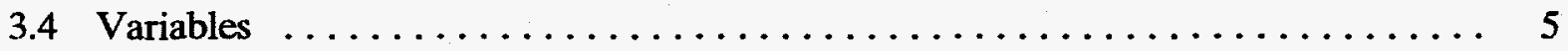

3.4.1 Schedule Variables $\ldots \ldots \ldots \ldots \ldots \ldots \ldots \ldots \ldots \ldots \ldots \ldots \ldots \ldots$

3.4 .2 Throughput and Capacity Variables $\ldots \ldots \ldots \ldots \ldots \ldots \ldots \ldots \ldots \ldots$

3.4.3 Soft Variables (Institutional, Regulatory, and Programmatic) . . . . . . . . 6

4. SCENARIOS $\ldots \ldots \ldots \ldots \ldots \ldots \ldots \ldots \ldots \ldots \ldots \ldots \ldots \ldots \ldots \ldots$

4.1 Base-Case Scenario $\ldots \ldots \ldots \ldots \ldots \ldots \ldots \ldots \ldots \ldots \ldots \ldots \ldots \ldots$

4.2 No Repository $\ldots \ldots \ldots \ldots \ldots \ldots \ldots \ldots \ldots \ldots \ldots \ldots \ldots \ldots$

4.3 Reduce Throughput $\ldots \ldots \ldots \ldots \ldots \ldots \ldots \ldots \ldots \ldots \ldots \ldots \ldots \ldots$

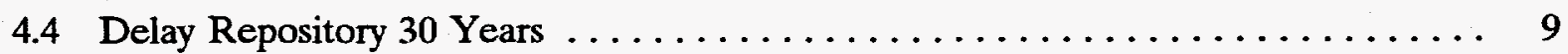

4.5 Delay Repository 30 Years, Renegotiate Milestones . . . . . . . . . . . . 9

5. ISSUES AFFECTING HLW TREATMENT STORAGE AND ULTIMATE DISPOSAL 11

6. REFERENCES $\ldots \ldots \ldots \ldots \ldots \ldots \ldots \ldots \ldots \ldots \ldots \ldots \ldots \ldots \ldots \ldots \ldots$

Appendix A-Example of Site Shipment Schedules . . . . . . . . . . . . . . . A-1

Appendix B-Site Issues $\ldots \ldots \ldots \ldots \ldots \ldots \ldots \ldots \ldots \ldots \ldots \ldots \ldots \ldots \ldots \ldots \ldots \ldots$ 


\section{FIGURES}

1. Three variables (shown in parenthesis) are used to model the transportation and disposal parts of the HLW system.

2. Schematic representation of the site-specific portion of the systems analysis model (variables

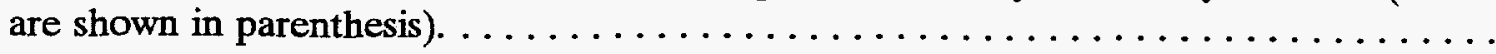




\section{National High-Level Waste Systems Analysis Plan}

\section{INTRODUCTION}

\subsection{Background}

At the present time, no mechanism exists that affords a systemized, interrelated view or national perspective of all high-level waste (HLW) treatment and storage systems that the U.S. Department of Energy (DOE) manages. The impacts of budget constraints and repository availability on storage and treatment must be assessed against existing and pending negotiated milestones for their impact on the overall HLW system. This assessment can give DOE a complex-wide view of the availability of waste treatment and help project the time required to prepare HLW for disposal. The complex array of facilities, throughputs, schedules, and milestones must be modeled to ascertain the treatment and storage "systems" resource requirements at Hanford, Savannah River Site (SRS), Idaho National Engineering Laboratory (INEL), and West Valley Demonstration Project (WVDP). The impacts of various treatment system availabilities on schedule and throughput can be compared to repository readiness to determine the prudent application of resources or the need to renegotiate court orders or consent order milestones. To assess and document the various impacts, the model will be exercised against a number of plausible scenarios and a follow-on report prepared.

Some HLW models are in existence or have been developed at the site level. The intent of this model is to use the efforts of others where possible and to research site data to complete the picture. The INEL will encourage the sites and focus areas to use this model when completed since it is a truly national perspective.

\subsection{Objectives}

The objectives of the National High-Level Waste System Analysis task are as follows:

- Produce a tool for use by the U.S. Department of Energy (DOE-HQ) staff that can evaluate the performance and consequences of HLW treatment, storage, and disposal options on a complex-wide basis

- Analyze the performance and consequences of HLW treatment, storage, and disposal options. 


\section{APPROACH}

The prototype version of the system model has been constructed using available hard data pertaining to schedules, processing options, and throughput. These data are more easily quantifiable and will simplify the tasks of building and testing the first model. The prototype version is constructed in such a way as to allow expansion to incorporate other, more qualitative factors in later revisions. The influence of qualitative factors (soft variables) can be evaluated with the prototype model by establishing discreet sets of input variables (scenarios) that reflect the consequences of soft variables. For example, the effects of stakeholder involvement could be modeled by manually fixing certain schedule dates that are used as input by the model, and letting the model calculate detailed schedule and throughput rates needed to meet the fixed schedule.

Experience gained during testing of the prototype will be used to expand and refine the model. Sensitivity analyses will demonstrate which variables have the most profound impacts on the output. Soft variables could be selected for more detailed modeling, and cost estimation could be coupled to the model. The cost of developing the model is minimized by incrementally incorporating selected enhancements to the prototype, as opposed to initially constructing a large, complex model that may include features that prove to be of little use.

While the prototype version of the model will not perform detailed cost estimation, throughput of both primary and secondary waste streams can be used to compare facility costs with the system cost model developed by Lockheed Idaho Technologies Company. The ability to analyze secondary waste stream volumes at the national level will allow shared capacity evaluation and analysis to be performed for treatment, storage, and disposal.

The model addresses system performance in terms of schedule and throughput; one can be selected as the independent variable. For example, schedule can be fixed in order to study the effects of legally binding agreements on facility size (throughput). Conversely, throughput can be fixed to examine the influence of budget constraints on the need to renegotiate existing agreements. Detailed schedules can be developed from higher level milestones, such as deadlines in consent orders driven by the Federal Facility Compliance Act (FFCA) or Federal Facility Agreements (tri-party).

HLW currently in storage will be treated as a "source," and the HLW repository will be treated as the "sink." Detailed flow sheets describing the wastes and treatment processes (existing or proposed) at each site managing HLW are used to model the preparation of HLW for shipment to the repository. The waste treatment and interim storage portions of the system come under DOE Environmental Management (EM) purview. The Office of Civilian Radioactive Waste Management (RW) is responsible for the transportation and disposal parts of the system. The transportation system and waste packaging operations at the repository will not be explicitly modeled, but their effects will be taken into account by the rate at which HLW is received at the repository and the repository capacity. The rate of HLW receipt is equivalent to the throughput of the transportation system. This aspect of the model is shown schematically in Figure 1. Both repository capacity for HLW and the throughput of the transportation system are defined in Table 3-2 of the Waste Acceptance System Requirements Document (WASRD) (RW 1993). See Appendix A for an example of site shipping rates. 


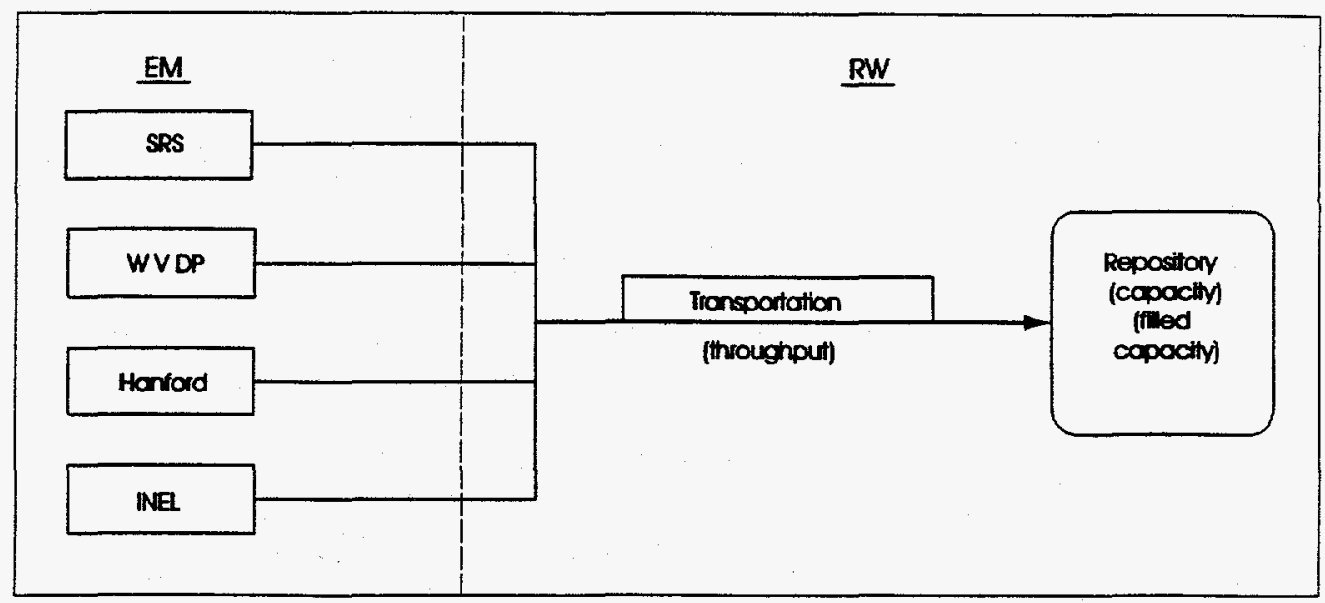

Figure 1. Three variables (shown in parenthesis) are used to model the transportation and disposal parts of the HLW system.

Waste treated at the individual sites flows through the transportation system at an integrated rate defined by the variable, throughput, and accumulates at the repository until the variable, capacity, reaches 1.0 ; this will represent that fraction of capacity that is filled. The areas of responsibility of EM and RW are illustrated in Figure 1. 


\section{DESCRIPTION OF THE MODEL}

\subsection{Model Capabilities}

The model programming language is Vensim, which has been developed recently, so the modeling capabilities are uniquely appropriate for this type of modeling because it uses standard convergence routines, is easily expandable, etc. In addition, the language is flexible and able to accommodate a wide range of variables, both soft (stakeholder, regulatory institutional) and hard (throughput, schedule, capacity).

The model is being developed using storage and treatment schemes determined by the individual sites according to their current preferred option. Information on the processes is obtained from DOE and contractor documents and from technical experts at the sites. All model input will be verified by site technical experts. The actual programming of the model is being validated and verified by an independent source.

\subsection{Vensim Specific Output}

The two main types of output from Vensim include strip and bar graphs, along with schedule-oriented Gantt charts. Multiple variables can be compared with each other by placing them on the same graph in different colors. In addition, scenario impacts can be compared by

placing the same variable on a single graph, with each scenario run being graphed in a different color. The graphs are usually time based, that is, time is usually the $y$-axis.

Tables can be used to see more detailed numbers on a more detailed time scale. Usually, each row in the table is a one-time step in the simulation (month, day, year), and each column represents a variable in the model. These tables can be imported onto spreadsheets to take advantage of the wider range of graphing options.

\subsection{General Assumptions and Constraints}

Several assumptions and constraints were considered in designing the model and are listed below:

- The repository will have the capacity to accept HLW as defined in Table 3-2 of the WASRD (RW 1993). (This variable can be changed to serve as an independent variable to study the effects of different repository sizes and/or multiple repositories.)

- Other wastes to be sent to the repository (such as commercial spent fuel) will not affect the shipment and handling of HLW.

- No additional HLW will be generated.

- $\quad$ All HLW will be treated at the site where it is presently stored. 
- Treatment options will be modeled either as established processes where construction is now complete (SRS and WVDP) or by using the latest information available on the currently preferred process option where treatment technology is still under development or the facility in design (INEL, Hanford).

- Immobilized waste will be shipped at the rates specified in Table 3-2 of the WASRD (RW 1993). These rates are actually rates of receipt at the repository, and so represent the sum of waste shipments from all sites (see Figure 1). The exact distribution of shipping capacity among the sites will be specified for each scenario (see Appendix A). (This assumption can be changed to serve as an independent variable reflecting limitations in repository handling capabilities and/or limitations in the transportation system.)

- All solidified HLW sent to a repository will be delisted, have a treatability variance approved, or be determined equivalent technology pursuant to 40 CFR 268, "Land Disposal Restrictions."

\subsection{Variables}

The model uses five hard variables to track system performance: start dates, end dates, throughput, capacities expressed as cubic meters, and filled capacity (as a fraction of capacity). The user can fix various combinations of these variables as independent variables, and allow the model to calculate the remaining variables as dependent variables. The model performs calculations as an incremental function of time to correlate schedule variables with throughput and filled capacity.

Waste treatment at each site is modeled by three top-level functions: HLW storage, treatment, and interim storage. Transfers between the functions are characterized by throughput variables. HLW storage and interim storage are characterized by capacities. The treatment function is derived as a roll-up of flow sheets describing the entire treatment process (existing or proposed) at each site. As such, the treatment function is described entirely by inputs and outputs. This feature allows the model to account for secondary waste streams, in addition to the primary high-level waste stream.

The waste treatment operations at each site couple to the repository through the transportation system. Since the total throughput of the transportation system is used to regulate the flow of waste into the repository, each site must be assigned its specific allotment of the total throughput of the transportation system. This feature allows the user to study trade-offs between treatment rates, interim storage rates, and schedule variables. The design of the site-specific portions of the model is illustrated schematically in Figure 2.

The treatment function is a roll-up of site-specific flow sheets (actual or proposed), and therefore can be used to account for secondary waste streams. 


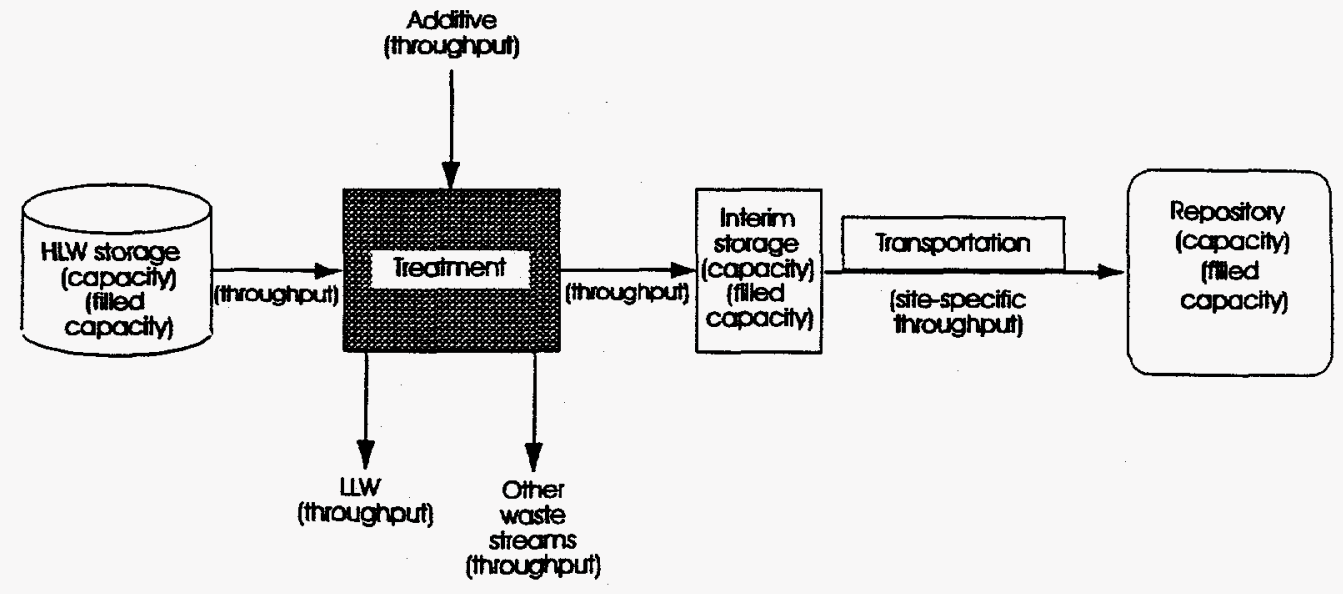

Figure 2. Schematic representation of the site-specific portion of the systems analysis model (variables are shown in parenthesis).

\subsubsection{Schedule Variables}

Schedule variables include new facility design, construction, and startup dates; existing facility campaign start and stop dates, as derived from court orders, consent orders, or Federal Facility Agreements requiring waste treatment, storage, or disposal actions and site operating plans. Dates for completion or commencement of tasks specified in court or consent orders, etc., can be included as milestones that trigger event flags if the milestones are missed. The flags are used to quickly identify problems with facility schedules and operating plans.

\subsubsection{Throughput and Capacity Variables}

Throughput and capacity variables include storage capacities, treatment process waste streams splits, waste stream volumes, etc. Secondary and tertiary waste streams will be included in the analysis, as they are key to the selection of treatment technologies. Included in throughput will be transportation assumptions for the repository, since the repository will likely choose to accept the treated HLW at a constant rate.

\subsubsection{Soft Variables (Institutional, Regulatory, and Programmatic)}

Institutional, programmatic, regulatory, financial, and technical issues may affect the performance of all or parts of the national HLW management system. Scenarios will be created that incorporate soft variable perturbations to the base-case scenario or to the other scenarios to help assess the impact of these issues on facility schedules, capacity, or throughput, and ultimately on the ability of sites to prepare HLW for shipment to the repository. 
Some examples of soft variables that may be used were developed from the perspective of stakeholder involvement and are listed below:

- Health and safety of public and workers during facility operations and storage of waste.

- Non-proliferation-preventing the ability to recover fissile materials.

- $\quad$ Risk of environmental release and effect of release.

- Spent nuclear fuel-the ability to use fissile material for power generation in the future.

- Low-level waste ( $\quad$ LWW) radioactivity-if waste is to be stored in their state, most citizens want the radioactivity as low as possible.

- Technical maturity-the time required to develop and implement the technology versus perceived risk and benefit derived by implementation

- Cost of treatment/technology development balanced by the risk of technology failure.

- Socioeconomic impacts-average yearly dollars to the local community. 


\section{SCENARIOS}

A given set of independent variables represents a "scenario." Once a scenario has been defined, dependent variables are calculated to provide the output. The output will include event flags to indicate if pre-selected conditions are not satisfied by the dependent variables when a scenario is analyzed.

Five specific scenarios will be examined with the initial model in order to identify national impacts and to demonstrate capabilities that stimulate more detailed analysis and identify areas for further development. The model will continue to be exercised as different scenarios are applied or as operational events occur that enable a comparison to be made to model output.

\subsection{Base-Case Scenario}

The base-case scenario will use a fixed schedule defined by existing court orders and agreements. For the base case, the repository will begin accepting $\mathrm{HLW}$ in 2015. A detailed waste treatment schedule will be developed from site operating plans and will include negotiated and envisioned milestones that take this data into account. Process throughput will be estimated, along with interim storage requirements. Repository receipts will be calculated using existing $\mathrm{RW}$ and EM documents designating shipping rates for final disposal. In the event that data is nonexistent, assumptions will be made and documented in the model.

\subsection{No Repository}

This scenario will also use a fixed schedule defined by existing court orders and negotiated agreements. A detailed waste treatment schedule will be developed, with process throughput and interim storage requirements being estimated from facility schedules and operating plans. The national repository is abandoned in lieu of monitored retrievable storage. In this scenario, the INEL's New Waste Calcining Facility will continue to operate to help empty the tank farm contents, as required by consent order (Idaho Department of Health and Welfare 1994) until a vitrification unit is designed, constructed, and begins operation. In addition, a separation facility will be employed that will reduce the fraction of high-activity waste requiring remote handling and storage (Murphy et al. 1995). This facility will create the need for a near-surface disposal facility for contact-handled waste stored in the Calcined Solid Storage Facility, which is designed for a 500-year storage life. WVDP will operate and shut down using SRS interim storage for the vitrified waste form. SRS will operate the Extended Wash Facility, Late Wash Facility, Effluent Treatment Facility, and the Consolidated Incineration Facility in conjunction with the Defense Waste Processing Facility (DWPF) and will store all vitrified waste in interim storage; this will require a larger capacity than was originally envisioned (Westinghouse Savannah River Company 1994). Hanford will construct and operate vitrification facilities for HLW and LLW per the TriParty Agreement. Hanford will provide the LLW near-surface disposal capacity required by the INEL (Westinghouse Hanford Company 1994). DOE will then size, construct, and operate an adequate facility for monitored retrievable interim storage to U.S. Nuclear Regulatory Commission requirements through 2100. 


\subsection{Reduce Throughput}

This scenario will perturb the base-case scenario by reducing throughput between HLW storage and the treatment facility at all sites by $30 \%$ and calculating a new schedule. This scenario would simulate a reduction in funding (assuming that construction funds for SRS and WVDP are already committed) and would be used to illustrate the impact on existing agreements and court orders. This scenario will facilitate closure of the WVDP site, limit the need for interim storage capacity at SRS, and minimize interim storage capacities at Hanford and the INEL. Interim storage capacities at Hanford and the INEL are minimized by delaying startup of $H L W$ immobilization and separation facilities until the repository is ready to receive waste shipments. Startup dates for SRS and WVDP remain unchanged, and startup dates for Hanford and the INEL are delayed to coincide with the beginning of HLW receipt at the repository (2015). Waste from WVDP will be shipped at a rate that will allow interim storage to be emptied in 1 year. Waste from SRS will be shipped at the production rate to avoid construction of new interim storage at that site. The remaining shipping capacity (throughput) will be divided between Hanford and the INEL in proportion to the site's production rate. unless an excess of throughput is realized as a result of production capacity limitations. If either Hanford or the INEL experiences an excess of throughput, the excess will be assigned to the other facility. If the combined production capacities of Hanford and the INEL cannot account for the combined throughput assigned to the two sites, the excess throughput will be assigned to SRS.

\subsection{Delay Repository 30 Years}

This scenario would re-compute the base case, with the repository opening delayed 30 years (to 2045). This scenario would illustrate the impact of a delay in repository operations on interim storage needs and would require additional construction. This case will assume that all current agreements and court orders are met other than those requiring deep geologic disposal. Minimization of interim storage would be accomplished by delaying startup of treatment at Hanford and the INEL until the repository opens. Production rates for both sites would be the same as in the base-case scenario. The transportation throughput available to each site would be determined as in Section 4.3. SRS and WVDP would proceed according to current schedules for waste immobilization. WVDP will ship waste at a rate to allow the site's interim storage to be emptied in one year. SRS will be assigned the remainder of the transportation throughput, until Hanford and the INEL come on line. At that time, SRS's share of the transportation throughput will be set equal to the production rate (throughput to interim storage), and the remainder of the transportation throughput will be divided between Hanford and the INEL as described in Section 4.3 This scenario would illustrate the latitude for adjustment in DOE's HLW treatment schedule, while minimizing interim storage costs and meeting all milestones in existing orders and agreements.

\subsection{Delay Repository 30 Years, Renegotiate Milestones}

This scenario would assume a 30-year delay in repository operations, and calculate new schedules for Hanford and the INEL, assuming minimal interim storage at those sites.

Minimization of interim storage would be accomplished by defining throughput from treatment to be equivalent to the transportation throughput, available to each site. The transportation 
throughput available to each site would be determined from the total transportation throughput available to the two sites divided proportional to the total amount of waste currently in storage. SRS and WVDP would proceed according to current schedules for waste immobilization. WVDP will ship waste at a rate to allow the site's interim storage to be emptied in 1 year. SRS will be assigned the remainder of the transportation throughput, until Hanford and the INEL come on line. At that time, SRS's share of the transportation throughput will be set equal to the production rate (throughput to interim storage), and the remainder of the transportation throughput will be divided between Hanford and the INEL as described above. This scenario would illustrate the latitude for adjustment in the DOE's HLW treatment schedule while minimizing interim storage costs and helping to define issues for renegotiating orders and agreements. 


\section{ISSUES AFFECTING HLW TREATMENT STORAGE AND ULTIMATE DISPOSAL}

Appendix B is a partial listing of institutional, programmatic, regulatory, financial, and technical issues by site that may affect the performance of all or parts of the HLW management system. These issues are being attached to show the types of issues that can perturb DOE's HLW management plans as reflected in the site operating plans. Scenarios to exercise the model will use different combinations of these issues for output to be analyzed by DOE-HQ. 


\section{REFERENCES}

Idaho Department of Health and Welfare, 1994, Consent Order for the United States Department of Energy, Idaho National Engineering Laboratory, April 3, 1992, as amended March.

Murphy, J. A., et al., 1995, ICPP Radioactive and Calcine Waste Technologies Evaluation and Final Report Recommendation, INEL-94/0119, Lockheed Idaho Technologies Company, April.

RW (Office of Civilian Radioactive Waste Management), 1993, Waste Acceptance System Requirements Document (WASRD), RW-0351P, Revision 0, January.

Westinghouse Hanford Company, 1994, Hanford Site Tank Waste Remediation System Technical Strategy, Revision 0, March 18.

Westinghouse Savannah River Company, 1994, High-Level Waste System Plan, Revision 4 (U), HLW-OVP-94-0145, November 30. 
Appendix A

Example of Site Shipment Schedules 

Table A-1. Example of site shipment schedules.

\begin{tabular}{|c|c|c|c|c|c|c|c|c|c|c|c|c|c|c|c|}
\hline \multirow[b]{2}{*}{ Year } & \multirow[b]{2}{*}{$\begin{array}{l}\text { Total glass } \\
\text { produced } \\
\left(\mathbf{m}^{3}\right)\end{array}$} & \multirow[b]{2}{*}{$\begin{array}{l}\text { Total } \\
\text { transportation } \\
\text { throughput } \\
\left(\mathrm{m}^{3}\right)\end{array}$} & \multirow[b]{2}{*}{$\begin{array}{c}\text { Total } \\
\text { glass in } \\
\text { interim } \\
\text { storage } \\
\left(\mathrm{m}^{3}\right)\end{array}$} & \multicolumn{3}{|c|}{ SRS } & \multicolumn{3}{|c|}{ WVDP } & \multicolumn{3}{|c|}{ Hanford } & \multicolumn{3}{|c|}{ INEL } \\
\hline & & & & $\begin{array}{l}\text { Treatment } \\
\text { storage } \\
\text { throughput } \\
\left(\text { ( }^{3} \text { of }\right. \\
\text { glass })\end{array}$ & $\begin{array}{l}\text { Annual } \\
\text { glass } \\
\text { slipment } \\
\left(\mathbf{m}^{3}\right)\end{array}$ & $\begin{array}{l}\text { Glass in } \\
\text { interim } \\
\text { storage } \\
\left(\mathrm{m}^{3}\right)\end{array}$ & $\begin{array}{l}\text { Treatment } \\
\text { storage } \\
\text { throughput } \\
\text { ( } \mathrm{m}^{3} \text { of } \\
\text { glass) }\end{array}$ & $\begin{array}{c}\text { Annual } \\
\text { glass } \\
\text { shipment } \\
\left(\mathrm{m}^{3}\right)\end{array}$ & $\begin{array}{l}\text { Glass in } \\
\text { interim } \\
\text { storage } \\
\left(\mathrm{m}^{3}\right)\end{array}$ & $\begin{array}{l}\text { Treatinent } \\
\text { storage } \\
\text { throughput } \\
\left(\operatorname{lin}^{3} \text { of }\right. \\
\text { (lass) }\end{array}$ & $\begin{array}{l}\text { Annual } \\
\text { glass } \\
\text { shipment } \\
\left(\mathbf{m}^{3}\right)\end{array}$ & $\begin{array}{l}\text { Glass in } \\
\text { interim } \\
\text { storage } \\
(\mathrm{m})\end{array}$ & $\begin{array}{l}\text { Treatment } \\
\text { storage } \\
\text { throughput } \\
\text { (m } \mathrm{m}^{3} \text { of } \\
\text { glass) }\end{array}$ & $\begin{array}{c}\text { Annual } \\
\text { glass } \\
\text { shipment } \\
\left(\mathbf{m}^{3}\right)\end{array}$ & $\begin{array}{c}\text { Glass in } \\
\text { interim } \\
\text { storage } \\
\left(\mathrm{m}^{3}\right)\end{array}$ \\
\hline 1996 & 142 & 0 & 142 & 142 & 0 & 142 & 0 & o & 0 & 0 & 0 & 0 & o & 0 & 0 \\
\hline 1997 & 455 & $\mathbf{0}$ & 455 & 142 & 0 & 285 & 171 & 0 & 171 & 0 & 0 & 0 & $\mathbf{0}$ & 0 & $\mathbf{0}$ \\
\hline 1998 & 654 & 0 & 654 & 142 & $0 \%$ & 427 & 56 & 0 & 227 & 0 & 0 & 0 & $\mathbf{0}$ & 0 & 0 \\
\hline 1999 & 796 & $\mathbf{0}$ & 796 & 142 & 0 & 569 & o & o & 227 & 0 & 0 & 0 & $\mathbf{0}$ & 0 & 0 \\
\hline 2000 & 939 & 0 & 939 & 142 & 0 & 712 & 0 & 0 & 227 & 0 & 0 & 0 & o & 0 & 0 \\
\hline 2001 & 1,081 & 0 & 1,081 & 142 & 0 & 854 & 0 & 0 & 227 & 0 & 0 & 0 & $\mathbf{0}$ & 0 & 0 \\
\hline 2002 & 1,223 & $\mathbf{0}$ & 1,223 & 142 & 0 & 996 & 0 & 0 & 227 & 0 & 0 & 0 & $\mathbf{0}$ & $\mathbf{0}$ & $\mathbf{0}$ \\
\hline 2003 & 1,366 & $\mathbf{0}$ & 1,366 & 142 & 0 & 1,139 & 0 & 0 & 227 & 0 & 0 & 0 & o & 0 & 0 \\
\hline 2004 & 1,508 & $\mathbf{0}$ & 1,508 & 142 & 0 & 1,281 & $\mathbf{0}$ & 0 & 227 & 0 & 0 & 0 & $\mathbf{0}$ & o & 0 \\
\hline 2005 & 1,650 & $\mathbf{0}$ & 1,650 & 142 & 0 & 1,423 & 0 & o & 227 & 0 & 0 & 0 & 0 & 0 & 0 \\
\hline 2006 & 1,793 & $\mathbf{0}$ & 1,793 & 142 & 0 & 1,566 & 0 & 0 & 227 & 0 & 0 & 0 & 0 & 0 & 0 \\
\hline 2007 & 1,935 & 0 & 1,935 & 142 & 0 & 1,708 & 0 & 0 & 227 & 0 & 0 & 0 & 0 & 0 & 0 \\
\hline 2008 & 2,077 & $\mathbf{0}$ & 2,077 & 142 & 0 & 1,850 & 0 & 0 & 227 & 439 & 0 & 0 & o & 0 & 0 \\
\hline 2009 & 2,650 & $\mathbf{0}$ & 2,858 & 142 & 0 & 1,992 & 0 & 0 & 227 & 439 & 0 & 439 & 0 & 0 & 0 \\
\hline 2010 & 3,239 & 0 & 3,239 & 142 & 0 & 2,135 & $\mathbf{0}$ & 0 & 227 & 439 & 0 & 877 & 0 & 0 & o \\
\hline 2011 & 3,820 & 0 & 3,820 & 142 & 0 & 2,277 & o & 0 & 227 & 439 & 0 & 1,316 & 0 & 0 & o \\
\hline 2012 & 4,400 & 0 & 4,400 & 142 & 0 & 2,419 & o & 0 & 227 & 439 & 0 & 1,754 & 0 & 0 & $\mathbf{0}$ \\
\hline 2013 & 5,044 & $\mathbf{0}$ & 5,044 & 142 & 0 & 2,562 & 0 & o & 227 & 437 & 0 & 2,193 & 63 & 0 & 63 \\
\hline 2014 & 5,688 & 0 & 5,688 & 142 & 0 \% & 2704 & 0 & 0 & 227 & 439 & 0 & 2,631 & 63 & 0 & 126 \\
\hline 2015 & 6,332 & 572 & 5,760 & 142 & 142. & 2704 & 0 & 227 & 0 & 439 & 171 & 2,692 & 63 & 25 & 163 \\
\hline 2016 & 6,975 & 572 & 5,831 & 142 & 142 . & 2704 & 0 & 0 & o & 439 & 376 & 2955 & 63 & 54 & 172 \\
\hline 2017 & 7,619 & 572 & 5,903 & 142 & 142 & 2704 & 0 & 0 & 0 & 439 & 376 & 3018 & 63 & 54 & 181 \\
\hline 2018 & 6,263 & 572 & 5,975 & 142 & 142 & 2704 & 0 & 0 & 0 & 439 & 376 & 3,080 & 63 & 54 & 190 \\
\hline 2019 & 8,906 & 572 & 6,046 & 142 & 142 . & 2704 & 0 & 0 & 0 & 439 & 376 . & 3,143 & 63 & 54 & 199 \\
\hline 2020 & 9,550 & 572 & 6,118 & 142 & 142 & 2,704 & o & o & 0 & 439 & 376 & 3,206 & 63 & 54 & 208 \\
\hline 2021 & 10,051 & 572 & 6,047 & 0 & 142 \% & 2,562 & 0 & o & 0 & 439 & 376 & 3,268 & 63 & 54 & 217 \\
\hline
\end{tabular}


Table A-1. (continued).

\begin{tabular}{|c|c|c|c|c|c|c|c|c|c|c|c|c|c|c|c|}
\hline \multirow[b]{2}{*}{ Year } & \multirow[b]{2}{*}{$\begin{array}{c}\text { Total glass } \\
\text { produced } \\
\left(\mathrm{m}^{3}\right)\end{array}$} & \multirow[b]{2}{*}{$\begin{array}{c}\text { Total } \\
\text { transportation } \\
\text { throughput } \\
\left(\mathrm{m}^{3}\right)\end{array}$} & \multirow[b]{2}{*}{$\begin{array}{c}\text { Total } \\
\text { glass in } \\
\text { interim } \\
\text { storage } \\
\left(\mathrm{m}^{3}\right)\end{array}$} & \multicolumn{3}{|c|}{ SRS } & \multicolumn{3}{|c|}{ WVDP } & \multicolumn{3}{|c|}{ Hanford } & \multicolumn{3}{|c|}{ INEL } \\
\hline & & & & $\begin{array}{l}\text { Treatment } \\
\text { storage } \\
\text { throughput } \\
\text { (m }{ }^{3} \text { of } \\
\text { glass) }\end{array}$ & $\begin{array}{c}\text { Annual } \\
\text { glass } \\
\text { shipnent } \\
\left(\mathrm{m}^{3}\right)\end{array}$ & $\begin{array}{l}\text { Glass in } \\
\text { nterim } \\
\text { storage } \\
\left(\mathrm{m}^{3}\right)\end{array}$ & $\begin{array}{l}\text { Treatment } \\
\text { storage } \\
\text { throughput } \\
\text { ( } \mathrm{m}^{3} \text { of } \\
\text { glass) }\end{array}$ & $\begin{array}{c}\text { Annual } \\
\text { glass } \\
\text { shipment } \\
\left(\mathrm{m}^{3}\right)\end{array}$ & $\begin{array}{c}\text { Glass in } \\
\text { interim } \\
\text { storage } \\
\left(\mathrm{m}^{3}\right)\end{array}$ & $\begin{array}{l}\text { Treatment } \\
\text { storage } \\
\text { throughput } \\
\left(\mathrm{m}^{3} \text { of }\right. \\
\left.\mathrm{g}^{\prime} \mathrm{s}\right)\end{array}$ & $\begin{array}{l}\text { Annuall } \\
\text { glass } \\
\text { hipment } \\
\text { (m) }\end{array}$ & $\begin{array}{l}\text { Glass in } \\
\text { interim } \\
\text { storage }_{\left(\mathbf{H}^{3}\right)}\end{array}$ & $\begin{array}{l}\text { Treatment } \\
\text { storage } \\
\text { throughput } \\
\text { (m }{ }^{3} \text { of } \\
\text { glass) }\end{array}$ & $\begin{array}{c}\text { Annual } \\
\text { glass } \\
\text { shipment } \\
\left(\mathrm{m}^{3}\right)\end{array}$ & $\begin{array}{c}\text { Glass in } \\
\text { interim } \\
\text { storage } \\
\left(\mathrm{m}^{3}\right)\end{array}$ \\
\hline 1996 & 142 & $\mathbf{0}$ & 142 & 142 & 0 & 142 & 0 & 0 & $\mathbf{0}$ & 0 & 0 & 0 & 0 & 0 & 0 \\
\hline 2022 & 10,553 & 572 & 5,977 & 0 & 142 & 2,419 & 0 & o & 0 & 439 & 376 & 3,331 & 63 & 54 & 226 \\
\hline 2023 & 11,054 & 572 & 5,906 & 0 & 142 & 2,277 & 0 & 0 & 0 & 439 & 376 & 3394 & 63 & 54 & 235 \\
\hline 2024 & 10,556 & 572 & 5,836 & 0 & 142 & 2,35 & 0 & 0 & 0 & 439 & 376 & 3,457 & 63 & 54 & 244 \\
\hline 2025 & 12,057 & 572 & 5,765 & 0 & 142 & 1,992 & 0 & 0 & 0 & 439 & 376 & 3519 & 63 & 54 & 253 \\
\hline 2026 & 12,558 & 572 & 5,694 & 0 & 142 & 1950 & 0 & $\mathbf{0}$ & 0 & 439 & 376 & 3,582 & 63 & 54 & 262 \\
\hline 2027 & 13,060 & 572 & 5,624 & 0 & 142 & 1708 & 0 & 0 & 0 & 439 & 376 & 3,646 & 63 & 54 & 271 \\
\hline 2028 & 13,561 & 572 & 5,553 & 0 & 142 & 1,586 & 0 & 0 & 0 & 439 & 376 & 3,707 & 63 & 54 & 280 \\
\hline 2029 & 13,624 & 572 & 5,044 & 0 & 142 & 1,423 & 0 & 0 & 0 & 8 & 376 & 3,332 & 63 & 54 & 289 \\
\hline 2030 & 13,687 & 572 & 4,535 & 0 & 142 & 1,281 & 0 & 0 & 0 & 0 & 376 & 2956 & 63 & 54 & 298 \\
\hline 2031 & 13,750 & 572 & 4,026 & 0 & 142 & 1,139 & 0 & 0 & 0 & 0 & 376 & 2,580 & 63 & 54 & 307 \\
\hline 2032 & 13,813 & 572 & 3,617 & 0 & 142 & 996 & 0 & 0 & 0 & 0 & 376 & 2,204 & 63 & 54 & 316 \\
\hline 2033 & 13,875 & 572 & 3,007 & 0 & 142 & 854 & 0 & 0 & 0 & 0 & 376 & 1,828 & 63 & 54 & 325 \\
\hline 2034 & 13,938 & 572 & 2,498 & 0 & 142 & 112 & 0 & 0 & 0 & 0 & 376 & 1,453 & 63 & 54 & 334 \\
\hline 2035 & 14,001 & 572 & 1,989 & 0 & 142 & 569 & 0 & 0 & 0 & 0 & 376 & 1,077 & 63 & 54 & 343 \\
\hline 2036 & 14,064 & 572 & 1,480 & 0 & 142 & 427 & 0 & 0 & 0 & 0 & 376 & 001 & 63 & 54 & 352 \\
\hline 2037 & 14,127 & 572 & 971 & 0 & 142 & 285 & 0 & $\mathbf{0}$ & 0 & 0 & 376 & 325 & 63 & 54 & 361 \\
\hline 2038 & 0 & 572 & 399 & 0 & 142 & 142 & 0 & 0 & 0 & 0 & 376 & 0 & 0 & 104 & 257 \\
\hline 2039 & 0 & 399 & 0 & 0 & 142 & 0 & 0 & 0 & 0 & 0 & 325 & 0 & 0 & 257 & 0 \\
\hline Totals & 14,127 & 14,127 & 0 & 3,558 & 3,558 & & 220 & 277 & & 8770 & 8,770 & & 1,572 & 1,572 & \\
\hline
\end{tabular}


Appendix B

Site Issues

B-1 


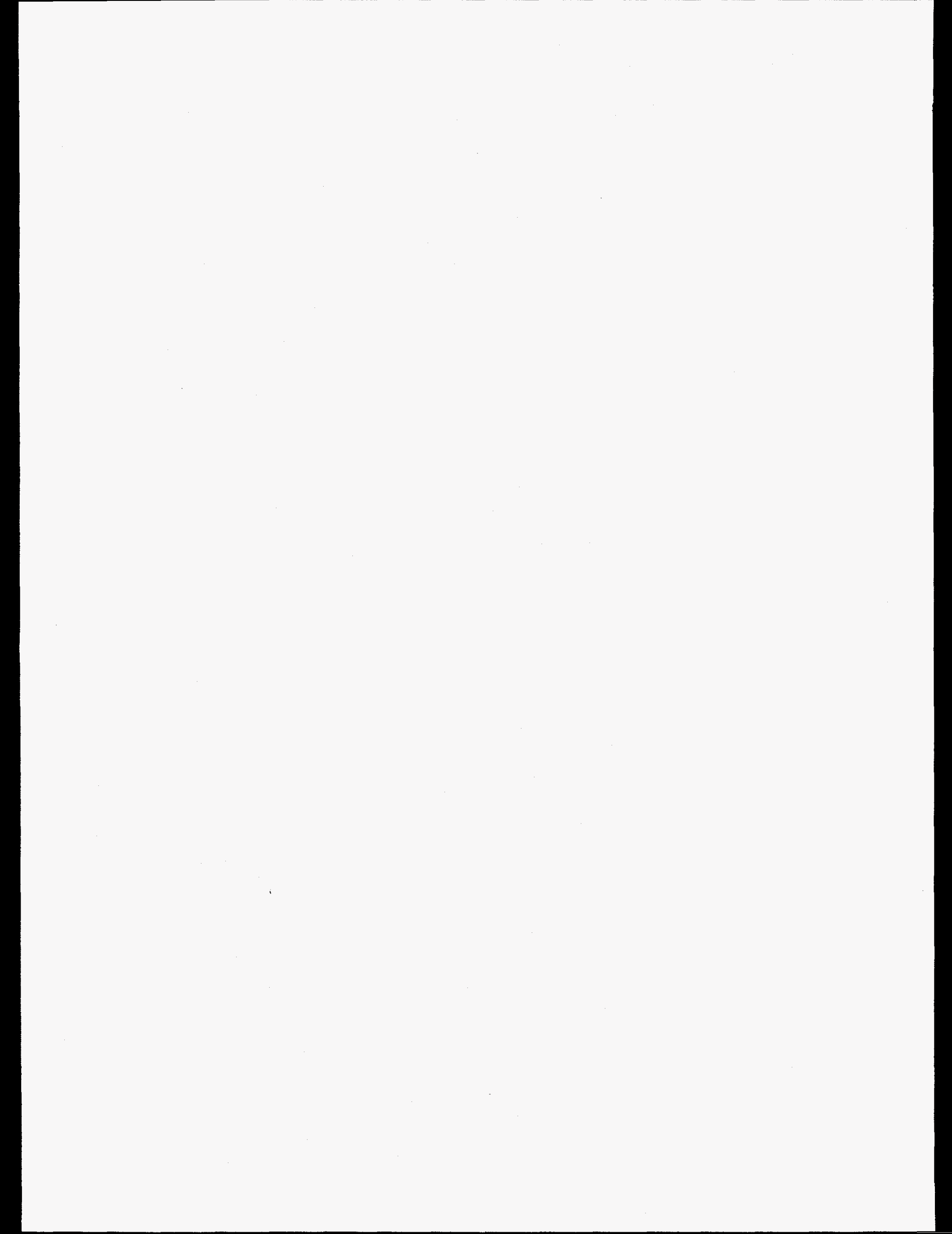


Table B-1. Site issues.

\begin{tabular}{|c|c|}
\hline Site & Issue \\
\hline Hanford $^{a}$ & $\begin{array}{l}\text { The methods required to mitigate or resolve the waste tank safety issues have } \\
\text { not yet been fully developed. For example, the proposed one-to-one dilution } \\
\text { may not be adequate and may require additional double storage tanks (DSTs) or } \\
\text { the removal and treatment of waste from some tanks. }\end{array}$ \\
\hline Hanford & $\begin{array}{l}\text { A retrieval sequence must be developed to support blending and process rates } \\
\text { necessary for storage, pretreatment, and vitrification of low-level waste (LLW) } \\
\text { and high-level waste (HLW). The current sequence retrieves waste from } 77 \text { of } \\
\text { the single storage tanks (SSTs) from } 2015 \text { to } 2018 \text {, which is a very high rate. If } \\
\text { this sequence does not match the needs for the other functions, significant } \\
\text { impacts will occur to cost and schedule for the Tank Waste Remediation System } \\
\text { (TWRS). }\end{array}$ \\
\hline
\end{tabular}

Hanford The initial criteria to retrieve 99\% of the waste from SSTs using past-practice sluicing may not be achievable, or they may not be adequate for closure.

The funding profile and schedules will be impacted significantly if removal processes for long-lived radionuclides and out-of-tank organic destruction are required.

Hanford

Sludge washing within the double-shell tanks may not be adequate. Waste blending to increase waste loading in the HLW and LLW forms may be severely impacted by tank space and retrieval system availability.

Hanford

If enhanced sludge washing is successful, the volume of vitrified HLW could be as low as $10,000 \mathrm{~m}^{3}$. Assuming $10-\mathrm{m}^{3}$ containers, the corresponding repository disposal fee would decrease to $\sim \$ 1.2$ billion (the cost profile used $\$ 2.7$ billion). However, the current estimates of spent nuclear fuel from power plants and defense HLW would require a second repository. This, coupled with the potential for a larger estimated amount of $\mathrm{HLW}\left(28,000 \mathrm{~m}^{3}\right.$ of glass) could increase the cost to more than $\$ 7$ billion.

Hanford

Geologic Repository Program acceptance of HLW canisters larger than 2-ft diameter $\mathrm{x} 10 \mathrm{ft}$ long has not been determined. If these canisters are not acceptable, costs could increase significantly.

Increase the amount of waste requiring treatment. Increase time for treatment. Increase time for treatment.

Increase the amount of waste requiring treatment.

Increase the time for treatment.

Increase the amount of waste requiring treatment.

Increase the time for treatment.

Increase the amount of waste requiring treatment.

Increase the time for treatment.

Increase the amount of waste requiring treatment.

Increase the time for treatment (if enhanced sludge washing is not successful).

Increase the time for treatment. 
Table B-1. (continued).

\begin{tabular}{ll}
\hline Site & Issue \\
\hline Hanford & Geologic repository acceptance of over packed cesium and strontium capsules
\end{tabular}

Hanford has not been pursued and will likely take several years to determine.

Hanford

Hanford

Hanford
The LLW Vitrification Facility will have minimal radiation shielding, based on removal of cesium and possibly strontium from the tank waste. This design may not be practical because of increased system costs (i.e., much greater pretreatment costs).

Hot (radioactive) pilot plants may be needed for pretreatment and melter development and testing; this would increase cost and delay schedule

The budget profile and forecasts are very preliminary. They may change significantly as the processes are defined, facilities are designed, and engineering estimates are made.

The once conservative funding assumptions used to build the Federal Facility Agreement (FFA) Waste Removal Plan and Schedule are no longer conservative. The tanks in sludge batches $\# 2$ and \#3 are now projected to meet the FFA dates "just in time." Further perturbations (such as emergent project needs and compliance program needs) to the planning bases could mean renegotiating these dates. Additional funding reductions similar to those experienced during development of the FY Annual Operating Plan (AOP) will definitely result in the need to renegotiate. It is not known how receptive the regulator will be to any changes.

Optimistic outyear funding expectations for the HLW system used in past fiveyear plans (FYPs) have historically eroded so that actual funding available for the AOP following the FYP is significantly less than expected. Over $\$ 800$ million of projected funding has been removed from the HLW program in the last 2 years. Current funding levels for the HLW system do not include any contingency for emergent work, although emergent work items are sure to occur. Emergent work takes the form of hardware, documentation, and implementing new programs.
Increase the amount of waste requiring treatment.

Increase the time for treatment.

None.

Delay facility startup.

None.

Increase time for treatment. Delay facility startup.

Increase time for treatment. Delay facility startup. 
Table B-1. (continued).

\begin{tabular}{|c|c|c|}
\hline Site & Issue & Effect on model \\
\hline SRS & $\begin{array}{l}\text { The HLW System Plan, parts of the FFA Waste Removal Plan and Schedule, } \\
\text { and most of the planned facility startups have no funding or schedule } \\
\text { contingency. Commercial nuclear and chemical industry history is quite clear on } \\
\text { the need for contingency in all planning activities, particularly in the "first-of-a- } \\
\text { kind" type of facilities described in the HLW System Plan. An argument could } \\
\text { be made that a plan with no contingency is predestined for cost overruns and } \\
\text { schedule delays. }\end{array}$ & Delay facility startup. \\
\hline SRS & $\begin{array}{l}\text { All of the waste in F-Area must eventually be transferred to H-Area for } \\
\text { pretreatment and disposal. Also, some of the dilute waste in H-Area must be } \\
\text { transferred to F-Area to balance the evaporator load. The F/H Inter-Area Line } \\
\text { (IAL) is currently not operable. It is required to be operational by } 3 / 97 \text { to } \\
\text { support the transfer of dissolved salt solution from Tank } 25 \text { to ITP. The scope, } \\
\text { schedule and estimate to restart operation of the F/H IAL are not known. } \\
\text { Funding has been allocated in FY } 1995 \text { but manpower has not. }\end{array}$ & $\begin{array}{l}\text { Increase time for treatment. } \\
\text { Delay facility startup. }\end{array}$ \\
\hline SRS & $\begin{array}{l}\text { Many HLW facilities constructed from the early } 1950 \text { s to the late } 1970 \text { s continue } \\
\text { to show signs of age. The Tanks } 1-8 \text { transfer line encasement in F-Area has } \\
\text { failed in one place and is leaking in several others. Groundwater leaking into } \\
\text { Tank } 19 \text { was detected in FY } 1994 \text {. Routine repairs to a steam regulator for the } \\
\text { 2F Evaporator escalated into } 3 \text { weeks of downtime as a result of the poor } \\
\text { condition of the service piping and obsolete instrumentation. The aging } \\
\text { problem is compounded by reduced budgets and extending the duration of the } \\
\text { HLW program. Aging facilities may cause excessive unplanned downtime, } \\
\text { addition of unplanned scope to existing projects, or the need for new line item } \\
\text { projects to ensure that the tank farm infrastructure will be able to support the } \\
\text { HLW program. }\end{array}$ & $\begin{array}{l}\text { Increase time for treatment. } \\
\text { Increase in waste requiring treatment. }\end{array}$ \\
\hline
\end{tabular}

Hundreds of millions of dollars of projected funding have been removed from

Increase time for treatment. the HLW program in the last 2 years. In order to balance near-term funding reductions, the duration of the HLW program has been extended. The funding required to keep the HLW facilities operational for the additional years amounts to billions of dollars in increased life-cycle costs 
Table B-1. (continued).

\begin{tabular}{llc}
\hline Site & Issue & Effect on model \\
\hline SRS &
\end{tabular}

SRS

SRS

There has been a steady stream of additional requirements and order compliance Increase time for treatment. programs that the operating divisions are required to support and implement. Most of these are difficult to forecast because they are continually emerging, with minimal involvement of all stakeholders, and have very short implementation commitments. Examples are Waste Certification, DNFSB 90-2, and the Price-Anderson Amendment Act. This is compounded by the lack of contingency funding, manpower, and schedules for other important activities.

The $2 \mathrm{~F}$ Evaporator has seven salt receipt tanks, six of which are full. The $2 \mathrm{H}$ Evaporator has two salt receipt tanks, with about one third of one tank of space remaining. The Replacement HLW Evaporator (RHLWE) will have one salt receipt tank when it starts up. The $2 \mathrm{H}$ Evaporator system is of greatest concern because of the small amount of salt space remaining and because the $2 \mathrm{H}$ Evaporator is needed to evaporate the future DWPF recycle stream. Also, it is difficult to measure the actual volume of saltcake in a tank because of the way the salt forms. The only planned method to remove salt depends on the startup of ITP, which is experiencing emerging work and other delays.

The DWPF Supplementary Environmental Impact Statements (EIS), the Waste Management Environmental Impact Statement (EIS), the Interim Nuclear Materials Management EIS, and the Plutonium Solutions Disposition EIS could have significant impacts on the startup schedules for ITP, Late Wash, and DWPF, as well as the decision to select the existing technology or process for each step in the HLW system. All of these EISs are on very tight schedules for development, approval, and publication of the record of decision (ROD).

Startups could be delayed if the EISs are delayed, or if the RODs include paths forward that are different from what is currently assumed in the HLW mission. A ROD of "No Action" could result in an indefinite delay in the execution of the HLW mission while alternative actions are being developed, therefore, leading to an increase in life-cycle cost to complete the HLW mission.

Increase time for treatment. Delay facility startup.

Delay ITP, late waste, and DWPF startups. 
Table B-1. (continued).

$\begin{array}{clc}\text { Site } & \text { Issue }\end{array}$

SRS

SRS

The startup of ITP, Extended Sludge Processing (ESP), Waste Removal, DWPF, Increase time for waste treatment. and Late Wash will significantly increase the analytical burden on the site laboratories. The attainment of each facility in the HLW system is dependent upon the timely turnaround of sample results. Analytical results are required in order to confirm that each processing step has been satisfactorily completed before proceeding to the next step. Future analytical needs for the HLW system may exceed the laboratory capabilities.

Recent safety studies for the DWPF have postulated new accident scenarios that Delay in DWPF startup. the current facility design does not adequately address. These accident scenarios will require upgrades of existing systems to higher safety classification. Facility modifications to achieve equivalent safety classification (to the degree appropriate for a backfit situation), along with additional administrative controls, are being pursued. Facility modifications have been proposed for the process vessel purging/inerting systems, the Zone 1 ventilation system and its supporting systems, the vitrification building effluent monitoring system, and select chemical storage tanks. These modifications will ensure that onsite and offsite personnel are adequately protected from exposure to radiological and nonradiological materials in the event of a design basis earthquake. However, the final cost of these modifications has not been confirmed, and the schedule to implement these changes could adversely impact the DWPF startup schedule.

Preliminary data from the ESP Process Verification Test indicate that the existing pumps in Tank 42 may not be able to suspend all of the sludge in the tank. This can affect washing, aluminum dissolution, and the size of the batch. In the worst case, the size of sludge batch \#1 could be what is currently in Tank Increase time for waste treatment. Increase the amount of waste requiring treatment. 51 , and all of the pumps in Tank 42 will have to be reworked or replaced with larger capacity pumps. If the sludge was not adequately suspended in the 1983 ESP demonstration, then additional aluminum dissolution could be required. A significant rework in Tank $\mathbf{4 2}$ is not scheduled or budgeted at this time. 
Table B-1. (continued).

\begin{tabular}{|c|c|c|}
\hline Site & Issue & Effect on model \\
\hline SRS & $\begin{array}{l}\text { Geotechnical, structural, and safety analyses for ITP were completed per the } \\
\text { Seismic Issues Resolution Program Plan. The present FY } 1995 \text { scope would } \\
\text { complete the resolution program for H-Area. Additional guidance from DOE } \\
\text { may require additional work in order to comply with emerging standards yet to } \\
\text { be agreed upon. Current funding levels for the Seismic Issues Resolution } \\
\text { Program do not cover some of this emerging work. }\end{array}$ & Delay in ITP startup. \\
\hline SRS & $\begin{array}{l}\text { Waste certification has evolved into a much more complicated set of } \\
\text { requirements than originally envisioned. The technical resources needed to } \\
\text { qualify the first waste form (solid low-level waste) exceeded all expectations. } \\
\text { Several waste forms, such as slurry pumps or other large and difficult to } \\
\text { decontaminate objects, may not meet the requirements for disposal without } \\
\text { considerable decontamination or assay operations. Facilities and manpower to } \\
\text { perform these new functions are not available and have not been forecasted. } \\
\text { Other important activities have already been affected by waste certification }\end{array}$ & Delay in time for waste treatment. \\
\hline
\end{tabular}

